\title{
Evaluation of tomato cultivars (Lycopersicon esculentum L.) at different sowing dates under the agro-climatic condition of Peshawar
}

Mohammad Ilyas ${ }^{1 *}$, Fida Muhammad Abbasi ${ }^{1}$, Muhammad Sajid ${ }^{1}$, Muhammad Adil ${ }^{1}$, Nasim Ahmad ${ }^{2}$, Naveed Ur Rehman ${ }^{1}$, Saboor Naeem ${ }^{1}$, Amjad Khan ${ }^{3}$, Farzana Begum ${ }^{2}$ and Gulzar Ullah ${ }^{4}$

1. Department of Agriculture Hazara University Mansehra-Pakistan

2. Agriculture Research System Khyber Pakhtunkhwa-Pakistan

3. Agriculture Research Station Baffa Mansehra-Pakistan

4. Department of Horticulture, The University of Agriculture, Peshawar-Pakistan

*Corresponding author's email: Ilyas_swati88@yahoo.com

Citation

Mohammad Ilyas, Fida Muhammad Abbasi, Muhammad Sajid, Muhammad Adil, Nasim Ahmad, Naveed Ur Rehman, Saboor Naeem, Amjad Khan, Farzana Begum and Gulzar Ullah. Evaluation of tomato cultivars (Lycopersicon esculentum L.) at different sowing dates under the agro-climatic condition of Peshawar. Pure and Applied Biology. Vol. 8, Issue 1, pp537-542. http://dx.doi.org/10.19045/bspab.2018.700214

Received: 15/10/2018 Revised: $30 / 11 / 2018$

Accepted: 04/12/2018

Online First: 08/12/2018

\section{Abstract}

A field trial was conductedto evaluate tomato cultivars at different sowing dates under the agro climatic condition of Peshawar. Randomized complete block design having three replications and two factors. I.e. cultivars (Roma, Rio Grande and Red Stone and sowing dates $1^{\text {st }}, 15^{\text {th }}$ and $30^{\text {th }}$ January was used. Both sowing dates and cultivars significantly affected the growth and yield parameters. Among different sowing dates $15^{\text {th }}$ January significantly increased flower cluster plant ${ }^{-}$ ${ }^{1}$, number of fruit cluster ${ }^{-1}$ and yield $\left(26.3 \mathrm{t} \mathrm{ha}^{-1}\right)$. Cultivar Red Stone significantly increased plant height, branches plant ${ }^{-1}$, flower cluster plant ${ }^{-1}$, fruit cluster ${ }^{-1}$ and yield $t \mathrm{ha}^{-1}$ ).It is concluded that tomato cultivar Red Stone sown after second week of January resulted in optimum growth and yield under the agro-climatic conditions of Peshawar.

Keywords: Cultivars; Growth; Quality; Sowing times; Tomato; Yield

\section{Introduction}

Tomato (Lycopersicon esculentum) is a herbaceous plant of Family Solanaceae. The Growth habits of tomato ranges from determinate to indeterminate type, giving fruits of different sizes and shapes. Tomato comes under the most popular vegetable in home gardens. Its origin is South America, In Europe it is also called as "Love Apple".
Tomatoes for the first time were raised by Thomas Jefferson for his guests in 1781 . Tomato fruits are used in salads and as a flavoring ingredients in soups, meat and fish dishes. Different forms of processed tomatoes are available which includes include sauces, pastes, ketchups and juices [1].Tomato needs a relatively cool, dry climate for optimum yield \&good quality. . 
Optimum temperature for normal growth and development of tomato plant is $21^{\circ} \mathrm{C}$ to $24^{\circ} \mathrm{C}$, itrequire below $21^{\circ} \mathrm{C}$ for fruit setting, and grows well in clay to sandy loam soil. The ideal $\mathrm{pH}$ range of soil for tomato growing is 6.0 to 6.5 [2].A seedbed of $50 \mathrm{~cm}$ wide at any convenient length in an area where sun light is maximum is suitable for tomato growth. Soil should be well ploughed and must be provided with decomposed compost or animal manure at the rate of about 1-2 $\mathrm{kg} / \mathrm{sqm}$. Irrigation of the seedbeds, thoroughly before sowing with recommended rows space of $5 \mathrm{~cm}$ having a seed rate of 150-200 seeds/hectare will result in higher yield of tomatoes., . Mulching of seedbed with thin layer of rice straw will decrease losses of water. . Tomato germinates in 3 to 6 days after sowing .Germination also depending upon temperature of the soil. At 3 to 5 days interval after germination thinning is required to provide more space between seedlings [3]. Roma is one of the tomato's cultivar in which fruits appear in Red colors, while leaves appear in Green and Olive color. Roma is a specific heirloom variety of tomato, although it is now (incorrectly) being used as a generic term for any tomato of the same shape and quality. The original, heirloom, Roma tomato was introduced in the 1950's. It is used for canning, paste, and sauce making [4]. Rio Grande tomato cultivar are determinate, medium i sized, with good cover and having joint less attachment, their fruits are long, square and oblong in shape, having an extra firmness, with a uniform green shoulder, averaging 129 - 135 grams, their fruits are smooth, thick walled, medium solid having high viscosity with a $\mathrm{PH}$ of 4.3 , while its Maturity required 125 days approximately. It is suitable for fresh market and processing. The fruits of Red stone cultivar are round and thin walled, fruits have more solids, with a $\mathrm{pH}$ of 5.0. It matures in approximately 110 days. It is suitable for marketand processing purposes, their plants are determinate, fruits are round in shape, and have good firmness, with a uniform green shoulder, having an average weight of about 120-124 grams [5]. Nutritional valve shows that Tomatoes are nutritious and having less calories. 6]. Tomatoes have a wide variety of shapes, sizes and colors, most common are the red tomato, yellow, orange and pink color tomatoes are also grown in different regions of the world,. Sizes vary from the bite-size cherry type tomato to the giant beefsteak tomatoes. Factors such as sowing dates and prevailing environmental conditions i.e. temperature and relative humidity etc. greatly affect plant growth and yield. Optimum temperature, low relative humidity and low rain fall during maturity resulted in higher yields [7], whereas, high temperature and humidity, increased susceptibility to fungal diseases. (Abdalla, 1969; Bisaria and Sham, 1979) concluded that environmental factors have great influence on growth and yield of crops. Time to flowering and duration of growth strongly influences the climatic adaptation and yield potential of a crop. Variations in both relative humidity and temperature affected both growth and flower production. Due to change in agro climatic conditions, periodic evaluation of sowing time is of urgent need. Keeping in mind the economic value of tomato and its daily uses there is a need to know about the best growing times for tomato therefore an experiment was carried to find out suitable sowing date and tomato cultivars for its optimum production in Peshawar Region.

\section{Materials and methods}

The proposed study entitled "Evaluation of tomato cultivars at different sowing dates under the agro climatic conditions of Peshawar was conducted at Horticulture farm, The University of Agriculture Peshawar. The experiment was laid out in randomized complete block design with two factors i.e. Sowing dates and tomato 
cultivars. The experimental filed was consist of twenty seven plots each of about $2.5 \mathrm{~m}^{2}$ with plant to plant and row to row distance of 30 and $100 \mathrm{~cm}$ respectively. Seedlings of available cultivars were transplanted on raised beds of about $45 \mathrm{~cm}$ in height. NPK fertilizerwas used @ 150:10060 kg ha ${ }^{-1}$.Half of the Nitrogen was applied at transplantation, while the remaining half was applied at two weeks interval. All the necessary cultural practices like hoeing, irrigation and weeding were carried out at proper time. Data were collected on plant height $(\mathrm{cm})$, number of branches plant ${ }^{-1}$, days to flowering, number of flower cluster plant ${ }^{1}$, number of fruits plant ${ }^{-1}$ and fruit yield tons $\mathrm{ha}^{-1}$.

\section{Statistical analysis}

Collected data was analyzed by using the statistix 8.1 software. According to [10] significant variation was get, mean data for all parameters was further analyzed for to know differences through least significant difference (LSD) test at (0.05) probability level.

\section{Results and discussion Plant height (cm)}

Data in the (Table) revealed that sowing dates showed non-significant effect on plant height, while cultivar and the interaction of sowing dates and cultivars was found significant for plant height. The tallest plant $(74.2 \mathrm{~cm})$ was recorded in Red stone followed by Rio Grande $(71.4 \mathrm{~cm})$, while smallest plant height $(62.5 \mathrm{~cm})$ was noted in cultivar Roma. In response to the interaction, tallest plants were noted in cultivar ed stone sown on $15^{\text {th }}$ January while minimum plant height $(58.5 \mathrm{~cm})$ was noted in Roma cultivar when sown on 1st January. The increased in plant height in mid of January might be due to suitable climatic conditions for better growth, consequently resulted in maximum height. [11] Concluded that maximum plant height $(189.2 \mathrm{~cm})$ and maximum yield was obtained when sowing was made in mid of January.

\section{Number of Branches plant ${ }^{-1}$}

Statistical analysis shows that number of branches plant ${ }^{-1}$ was significantly affected by sowing dates and cultivar, while their interaction was not significant. Maximum number of branches plant ${ }^{-1}$ (7.7) was recorded on 3oth January followed by (6.7) on $15^{\text {th }}$ January, while minimum number of branches plant $^{-1}$ (5.9) were recorded on

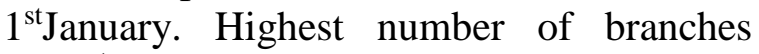
plant $^{-1}$ (7.2) was recorded by cultivar Red Stone followed by Rio Grande (6.7), while minimum number of branches plant ${ }^{-1}$ (6.2) was noted by cultivar Roma. The same result was also achieved by [9], who reported that Sowing dates and cultivars significantly increased number of branches per plant in tomato cultivar Posa. [12] Reported that growing cultivar Red stone increased biomass of tomato, quality of fruits and tomato fruits yield.

\section{Days to flowering}

Statistical analysis shows that days to flowering was significantly affected by days to sowing, while cultivar and interaction show non-significant effect on days to flowering. Minimum number of days (34.3) was taken by cultivars sowing on $30^{\text {th }}$ January, followed (35.0) days by sowing on $15^{\text {th }}$ January, while maximum (37.0) days was taken by sowing cultivars on $1^{\text {st }}$ January.

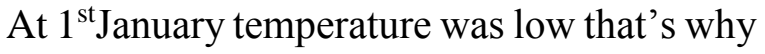
tomato plants took more days to flowering. On $15^{\text {th }}$ January temperature was increased as compared to first January so tomato plants took less days as compare to $1^{\text {st }}$ January. On $30^{\text {th }}$ January temperature was high as compared to $1^{\text {st }}$ and $15^{\text {th }}$ January, for this reason tomato plants reached early to flowering. The same result was also obtained by [13] who stated that sowing tomatoes in warm climatic conditions reached early to maturity as compared to cold climate. [13] Observed that sowing tomatoes at the end of January showed significant increase in stem length, number of branches, total leaf area, 
fresh and dry weights. While sowing tomatoes at the end of January reached early to maturity.

\section{Number of flower cluster plant ${ }^{-1}$}

Sowing dates and cultivars showed significant results for number of flower cluster plant $^{-1}$, while interaction was not significant. Mean table shows that more number of flower cluster $\operatorname{plant}^{-1}(26.3)$ were noted on $15^{\text {th }}$ January followed by (23.6) on $30^{\text {th }}$ of January. While minimum flower clusterplant $^{-1}$ (21.7) was recorded on $1^{\text {st }}$ January. The highest flower cluster plant ${ }^{-1}$ (26.9) was recorded by Red Stone, followed (23.7) by Rio Grande. While the lowest flower clusters (20.9) plant $^{-1}$ were rerecorded by cultivar Roma. In response to the interaction of sowing dates and cultivars maximum number (29.3) of flower cluster plant $^{-1}$ was recorded on $15^{\text {th }}$ of January by Red stone cultivar, while less number (18.2) of flower cluster plant ${ }^{-1}$ were noted on $1^{\text {st }}$ January by cultivar Roma. Same results were also obtained by [14] who stated that cultivar Red Stone and PossaRaby gives highest (29)flower cluster plant ${ }^{-1}$ followed by Roma which gives (23)flower cluster plant ${ }^{-1}$. [15] Concluded that maximum number of flower cluster plant ${ }^{-1}$ (28.34) were recorded with sowing cultivars in the mid of January because climatic conditions were much favorable for tomato production.

Table 1. Effect of sowing dates on growth and yield of tomato cultivars

\begin{tabular}{|c|c|c|c|c|c|c|}
\hline $\begin{array}{l}\text { Sowing dates } \\
\text { (SD) }\end{array}$ & $\begin{array}{l}\text { Plant } \\
\text { Height } \\
\text { (cm) }\end{array}$ & $\begin{array}{c}\text { No of } \\
\text { Branches } \\
\text { plant }^{-1}\end{array}$ & $\begin{array}{l}\text { Days to } \\
\text { flowering }\end{array}$ & $\begin{array}{c}\text { Number of } \\
\text { flower cluster } \\
\text { plant }^{-1}\end{array}$ & $\begin{array}{c}\text { Number of } \\
\text { fruits } \\
\text { cluster }^{-1}\end{array}$ & $\begin{array}{l}\text { Fruit yield (t } \\
\left.\qquad \mathbf{h a}^{-1}\right)\end{array}$ \\
\hline 01 January & 69.5 & $5.9 \mathrm{c}$ & $37.0 \mathrm{a}$ & $21.7 \mathrm{c}$ & $3.9 \mathrm{~b}$ & $21.8 \mathrm{c}$ \\
\hline 15 January & 70.0 & $6.7 \mathrm{~b}$ & $35.0 \mathrm{~b}$ & $26.3 \mathrm{a}$ & $4.1 \mathrm{a}$ & $26.3 \mathrm{a}$ \\
\hline 30 January & 69.6 & $7.7 \mathrm{a}$ & $34.3 \mathrm{~b}$ & $23.6 \mathrm{~b}$ & $3.8 \mathrm{ab}$ & $24.0 \mathrm{~b}$ \\
\hline Significance & $\mathrm{NS}$ & 0.67 & 1.38 & 1.33 & 0.27 & 1.33 \\
\hline \multicolumn{7}{|l|}{ Cultivars C) } \\
\hline Roma & $62.5 \mathrm{c}$ & $6.2 \mathrm{c}$ & 35.3 & $20.9 \mathrm{c}$ & $3.4 \mathrm{c}$ & $21.0 \mathrm{c}$ \\
\hline Rio Grande & $71.4 \mathrm{~b}$ & $6.7 \mathrm{~b}$ & 35.4 & $23.7 \mathrm{~b}$ & $3.8 \mathrm{~b}$ & $24.0 \mathrm{~b}$ \\
\hline Red Stone & $64.2 \mathrm{a}$ & $7.2 \mathrm{a}$ & 35.7 & $26.9 \mathrm{a}$ & $4.5 \mathrm{a}$ & $27.0 \mathrm{a}$ \\
\hline Significance & 2.5 & 0.67 & NS & 1.33 & 0.27 & 1.33 \\
\hline \multicolumn{7}{|l|}{ Interaction } \\
\hline $\mathrm{SD}^{*} \mathrm{C}$ & 4.4 & NS & NS & 2.30 & NS & NS \\
\hline
\end{tabular}

Means followed by same letter (s) do not differ significantly from one another at 5\% probability level, using LSD test

\section{Number of fruits cluster-1}

Number of fruit cluster ${ }^{-1}$ was significantly affected by sowing dates and cultivar, while their interaction had no significant effect. Maximum number (4.1) of fruits cluster ${ }^{-1}$ were noted on 15th January, while minimum number (3.9) and (3.8) of fruits cluster ${ }^{-1}$ was recorded on $1^{\text {st }}$ and $30^{\text {th }}$ January. Maximum fruit cluster $^{-1}$ (4.5) were recorded by Red stone followed by (3.8) by cultivar Rio Grande and Roma.The increase in fruit cluster $^{-1}$ may be because of the availability of suitable climatic conditions. [16] Observed that warm climate had significant role in maintenance of cell turgidity, increased respiration process and increased fruit setting. He stated that maximum fruits per cluster (9.2) were achieved by sowing tomato cultivars on the second decade of January. [17] Evaluate the response of sowing dates on yield and growth of tomato. They explore that growing tomatoes in summer gives good results as compared to winter. Tomatoes were sown in summer and in winter and parameters regarding quality and yield i.e. height of plant $(\mathrm{cm})$ and number of branches 
per plant were studied. They concluded that summer tomato gives good result as compared to winter tomatoes, because of the temperature factor.

Fruit yield $\left(\mathrm{t} \mathrm{ha}^{-1}\right)$

Fruit yield was significantly affected by sowing dates, cultivar and their interaction. Sowing in Mid of January resulted in increased fruit yield $\left(26.3 \mathrm{t} \mathrm{ha}^{-1}\right)$ followed by (24.0t $\mathrm{ha}^{-1}$ ) on $30^{\text {th }}$ January, while early sowing produced minimum fruits yield (21.8 $\left.\mathrm{t} \mathrm{ha}^{-1}\right)$. Cultivar Red Stone resulted in maximum fruits yield $\left(27.0 \mathrm{t} \mathrm{ha}^{-1}\right)$, followed by Rio Grande ( $24 \mathrm{t} \mathrm{ha}^{-1}$ ), while lowest fruit yield $\left(21 \mathrm{t} \mathrm{ha}^{-1}\right)$ was noted by cultivar Roma. The interaction of sowing dates and cultivars showed that higher fruit yield $\left(29.1 \mathrm{t} \mathrm{ha}^{-1}\right)$ was noted on $15^{\text {th }}$ January by Red Stone cultivar, while minimum yield (18.2 $\left.\mathrm{tha}^{-1}\right)$ was noted on $30^{\text {th }}$ January by cultivar Roma. Our results are closely related to that of [16] who stated that sowing tomato in the mid of January considerable increased the number of fruit (11) and fruit yield (35t ha-1). Hussain et al. (1989) reported that sowing Red Stone and Roma tomato cultivars resulted higher yield and yield components of tomato as compared to other cultivars. [18] Conducted an experiment on the effects of different sowing dates to the yield of tomato cultivar Roma. They noted that highest number of fruits plant $^{-1}$ (44), number of fruits plot ${ }^{-1}$ (704), yield per plant $(0.79 \mathrm{~kg})$, yield per plot $(12.78$ $\mathrm{kg}$ ) and yield tons per hectare (18.21) by sowing tomatoes in the mid of January.

\section{Conclusions}

Based on the data collected, it is concluded that Red stone tomato cultivar grown on $15^{\text {th }}$ January gave higher growth and yield under the agro-climatic condition of Peshawar and hence recommended for better growth and maximum yield under the agro climatic conditions of Peshawar region.

\section{Authors' contributions}

Conceived and designed the experiments: M.Ilyas, Fida Muhammad \& M Sajid,
Performed the Experiments: $M$ Ilyas, Analyzed the Data: M Adil, Contributed reagents/ materials/ analysis tools: N.Ahmad and A. Khan, Wrote the paper: M Ilyas, $\mathrm{N}$ Rehman, S Naeem \& M. Adil.

\section{References}

1. Smith PG, Vilalon B \& Vila PL (2004). Horticultural Classification of tomato growth in United States. Hort Sci 22: 1113.

2. Cebula S (1992). The effect of sowing and planting dates on the growth and yield of tomato in green house conditions. Folia Horti 4(2): 15-23

3. Nicklow GW \& Minges PA (1962). Plant growing factors affecting the performance of fireball tomato variety. Prac Amer Soc Hort Sci 81: 443-450.

4. Klassen YK (1993). Tomato gene encoding a basic pathogenesis related protein in pathogen and ethylene inducible. Physiologiaplantarum 108(1): 51-60.

5. Sajjan SB (2002). Effect of sowing dates on the growth and yield of tomato in alphine area. RDA Agri Sci Hort 35(1): 495-500.

6. Lerner SC (2004). Tomato crop in vegetable growing. Agrobiose, New Dehli, India. pp 59-61.

7. Delouche J (1980). Environmental effects on seed development and quality. J of Horti Sci (15): 775-780.

8. Abdalla AA (1969). Okra variety trial at Shambat. Sudan Agri J 4(2): 23-31.

9. Bisaria AK \& Sham SAP (1979). Effect of different seasons on growth and yield attributes of okra (Abelmoschus esculentus L. Moench.). Haryana $J$ of Horti Sci 8(3-4): 156-157.

10. Sandhu MS, Jaspreet S, Daljit J, Singhand \& Singh D (1999). Effect of training system on fruit yield and quality attributes of different tomato cultivars. Deptt Vege Crops, Pujnab Agri Uni Ladhiana. Veg Sci 26(2): 201-202. 
11. Sharma SK (1995). Response of boron and calcium nutrition on plant growth, fruit and seed yield of tomato. Vege Sci 22: 27-29.

12. Dube US \& Tripathi SK (2003). Response of micronutrients and sowing dates to growth, yield and quality of tomato Cv. Pusa Ruby in MP. Crop Res 12: 61-64.

13. Ilyas AF (2004). Vegetable crops. Horticulture National Book Foundation Islamabad. pp 489-509.

14. Naz RMM, Muhammad S, Hamid A \& Bibi F (2012). Effect of boron on the flowering and fruiting of tomato. Sarhad J Agri 28(1): 37-40.
15. Patil VK, Yadlod SS, Tambe TB \& Narsude PB (2010). Effect of foliar application of micronutrients on flowering and fruit set of tomato cv. Phule Raja. Int J Agri Sci 6(1): 164-166.

16. Dey SC (2000). Tomato crop in vegetable growing. Agrobiose, New Dehli, India. pp 59-61.

17. Singh SS \& Verma SK (2004). Influence of cultivars and sowing dates on growth and yield of tomato. Veg Sci 19(3): 121128.

18. Yadav M, Singh DB, Chaudhary R \& Reshi TA (2006). Effect of boron on yield of tomato cv. DVRT-1. J Plant Archive 6(1): 383. 